\title{
PENINGKATAN KOMPETENSI GURU DALAM MERANCANG PERANGKAT PENILAIAN HASIL BELAJAR MELALUI IN HOUSE TRAINING (IHT) DI SMPN 5 KECAMATAN HARAU
}

\author{
Rosmaliwarnis \\ Kepala SMPN 5 Kecamatan Harau \\ Email: rosmaliwarnis123@gmail.com
}

\begin{abstract}
This research is a School Action Research (SAR), through In House Training (IHT) to improve teacher competence in designing learning outcome assessment tools at SMPN 5 Harau District. This research was motivated by the lack of motivation and understanding of teachers in designing assessment tools. based on the results of preliminary studies conducted with several teachers of SMPN 5 Harau District, it was revealed that they generally had difficulty understanding learning outcomes assessment. The teacher has not designed the questions based on the question grid.

The findings of the study showed that the increase in teacher competence in designing the lattice for daily test questions was $86.25 \%$ with two indicators still lacking, namely $37.5 \%$ and $25 \%$. After the implementation of cycle II, the average score for teachers increased to $98.75 \%$. In the lattice-based question-making competency, an increase of $9.90 \%$ was obtained from the first cycle of $87.14 \%$ and the second cycle of $97.04 \%$. The results of the implementation of In House Training (IHT) showed that the teachers of SMPN 5 Harau District gained insight into knowledge, understanding the concept of assessment, and were skilled at developing assessment instruments to measure the competence of knowledge and skills of students.
\end{abstract}

Keywords: Assessment of learning outcomes, teacher professional competence, In House Training (IHT)

\begin{abstract}
ABSTRAK
Penelitian ini adalah Penelitian Tindakan Sekolah (PTS), melalui In House Training (IHT) untuk meningkatkan kompetensi guru dalam merancang perangkat penilaian hasil belajar di SMPN 5 Kecamatan Harau. Penelitian ini dilatarbelakangi oleh masih rendahnya motivasi dan pemahaman guru dalam merancang perengkat penilaian. karena berdasarkan hasil studi awal yang dilakukan dengan beberapa guru SMPN 5 Kecamatan Harau terungkap bahwa mereka pada umumnya mengalami kesulitan dalam memahami penilaian hasil belajar. Guru belum merancang soal berdasarkan kisi-kisi soal. Temuan penelitian menunjukkan peningkatan kompetensi guru dalam merancang kisi-kisi soal ulangan harian sebesar 86,25\% dengan dua indikator masih kurang yaitu dengan nilai $37,5 \%$ dan $25 \%$. Setelah pelaksanaan siklus II perolehan rata-rata nilai guru meningkat menjadi
\end{abstract}


98,75\%. Pada kompetensi pembuatan soal berasarkan kisi-kisi diperoleh peningkatan sebesar 9,90\% dari siklus I 87,14\% dan siklus II 97,04\%. Hasil kegiatan pelaksanaan In House Training (IHT) menunjukkan guru-guru SMPN 5 Kecamatan Harau mendapatkan wawasan pengetahuan, pemahaman konsep penilaian, dan terampil menyusun instrumen penilaian untuk mengukur kompetensi pengetahuan dan keterampilan peserta didik.

Kata kunci: Penilaian hasil belajar, kompetensi profesional guru, In House Training (IHT)

\section{PENDAHULUAN}

Penilaian adalah salah satu tugas pokok guru yang harus dilaksanakan dalam rangka mengetahui apakah proses pembelajaran dapat dipahami dan dimengerti oleh peserta didik. Peniliaian merupakan bagian yang penting dalam pembelajaran. Melalui penilaian yang baik dan akurat, guru dapat mengetahui tujuan pembelajaran sudah tercapai atau belum. Kemdikbud (2017) menjelaskan bahwa penilaian hasil belajar adalah proses pengumpulan dan pengolahan informasi yang digunakan guru untuk mengukur proses dan hasil pencapaian kompetensi peserta didik.

Dengan melakukan penilaian, pendidik sebagai pengelola kegiatan pembelajaran dapat mengetahui kemampuan yang dimiliki peserta didik, ketepatan metode mengajar yang digunakan, dan keberhasilan peserta didik dalam meraih kompetensi yang telah ditetapkan. Hasil penilaian dapat digunakan untuk pengambilan keputusan dalam rangka menentukan Langkah yang akan diamabil oleh seorang guru. Dari hasil penilaian guru dapat mengetahui peserta didik yang berprestasi dan yang perlu bimbingan lebih lanjut atau diperlukan pembelajaran remedial.

Penilaian pembelajaran dapat dilakukan guru seperti ulangan harian, ulangan tengah semester, maupun ulangan semester atau kenaikan kelas. Penilaian pembelajaran merupakan komponen penting dalam Pendidikan untuk melihat perkembangan dan tingkat pencapaian hasil belajar peserta didik. Penilaiam merupakan gambaran sebuah keberhasil dari sebuah pembelajaran di kelas. Melalui penilaian guru akan memperoleh informasi terhadap perkembangan pembelajaran peserta didik. Dengan demikian, semakin baik sebuah penilaian maka semakin baik pula informasi yang diperoelh.

Dari uraian di atas dapat dijelaskan bahwa penilaian hasil belajar yang baik sangat berpengaruh terhadap keberhasilan peserta didik. Penilaian yang baik akan memberikan hasil dan informasi yang baik pula. Dengan penilaian, guru dapat mengukur ketercapaian komptensi yang diajarkan. Pengukuran yang dilaksakan guru dalam rangka pemberian angka terhadap kegiatan pembelajaran. Kemdikbud (2017) menjelaskan Penilaian adalah proses pengumpulan dan pengolahan informasi untuk mengukur pencapaian hasil belajar peserta didik. Pengumpulan informasi tersebut ditempuh melalui berbagai teknik penilaian, menggunakan berbagai instrumen, dan berasal dari berbagai sumber.

Dari uraian di atas, maka guru perlu memahami dan memiliki kompetensi dalam melaksanakan penilaian pembelajaran dengan baik. Rusman (2012) menjelaskan bahwa kompetensi guru merupakan kemampuan guru dalam melaksanakan tugasnya dengan tanggung jawab. Guru merupakan tenaga profesional yang bekerja sesuai dengan keahlian yang dimiliki. Namun, berdasarkan hasil pantauan 
peneliti melalui supervisi perangkat pada semester 2 tahun pelajaran 2018/2019 dan wawancara singkat dengan beberapa orang guru diketahui bahwa guru belum memiliki perangkat penilaian yang lengkap. Para guru juga menjelaskan bahwa mereka lebih sering mengambil soal-soal untuk penilaian dari buku atau lembar kerja siswa. Guru lebih cendrung menyalin ulang soal-soal yang ada dari pada merakit soal sendiri.

Selanjutnya, guru belum terbiasa untuk merencanakan dan mengembangkan instrumen penilaian hasil belajar sendiri. Biasanya instrument penilaian untuk ulangan semester dikerjakan oleh tim dari MGMP setiap mata pelajaran. Jadi guru terbiasa manja dan menerima soal siap pakai di sekolah. Padahal dengan merancang dan melaksanakan penilaian hasil belajar adalah untuk menunjang penyelesaian tugas-tugas professional guru itu sendiri. Berdasarkan permasalahan tersebut, peneliti berkeinginan untuk membantu guru dalam merancang perangkat penilaian melalui Penelitian Tindakan Sekolah (PTS) dengan judul "Peningkatan Kompetensi Guru dalam Merancang Perangkat Penilaian Hasil Belajar melalui In House Training (IHT) di SMPN 5 Kecamatan Harau Tahun Pelajaran 2019/2020". Danim (2012) menjelaskan In House Training adalah pelatihan yang dilaksanakan secara internal oleh kelompok kerja guru, sekolah atau tempat lain yang ditetapkan sebagai penyelenggaraan pelatihan. Pelatihan dilakukan untuk meningkatkan kompetensi dan karier guru secara internal oleh guru sebagai trainer yang memiliki kompetensi yang belum dimiliki oleh guru lain. Ketentuan peserta dalam In House Training minimal 4 orang dan maksimal 15 orang.

Dari latarbelakang masalah di atas dapat diidentifikasi masalah penelitian Tindakan sekolah ini sebagai berikut:

1. Guru belum memahami dan mampu melaksanakan penilaian pembelajaran dengan baik

2. guru belum memiliki perangkat penilaian yang lengkap

3. guru lebih sering mengambil soal-soal untuk penilaian dari buku atau lembar kerja siswa

4. Guru lebih cendrung menyalin ulang soal-soal yang ada dari pada merakit soal sendiri

5. guru belum terbiasa untuk merencanakan dan mengembangkan instrumen penilaian hasil belajar

Masalah penelitian ini dibatasi tentang Peningkatan Kompetensi Guru dalam Merancang Perangkat Penilaian Hasil Belajar melalui In House Training (IHT) di SMPN 5 Kecamatan Harau Tahun Pelajaran 2019/2020

Permasalah penelitian dirumuskan sebagai berikut: "Apakah melalui In House Training (IHT) dapat meningkatkan kompetensi guru dalam merancang perangkat Penilaian hasil belajar melalui In House Training (IHT) di SMPN 5 Kecamatan Harau Pada Tahun Pelajaran 2019/2020?"

Penelitian ini bertujuan untuk meningkatkan kompetensi guru dalam merancang perangkat penilaian hasil belajar melalui In House Training (IHT) di SMPN 5 Kecamatan Harau Pada Tahun Pelajaran 2019/2020

Penelitian ini diharapkan bermanfaat untuk:

1 Secara teoritis diharapkan dapat memperkaya khasanah pengembangan keilmuan dan dapat dijadikan masukan untuk kajian lebih lanjut bahwa In House Training (IHT) dapat meningkatkan kompetensi guru dalam merangcang perangkat penilaian. 
2 Kepala Sekolah, sebagai seorang supervisor dapat menjadikan penelitian ini sebagai pedoman untuk melaksanakan tindak lanjut terhadap permasalahan yang ditemui di sekolah.

3 Bagi guru dapat memberikan manfaat yang besar dalam penyusunan perangkat penilaian, sehingga mampu meningkatkan kualitas penilaian yang akan berdampak pada kualitas hasil pembelajaran.

\section{METODE PENELITIAN}

Penelitian ini adalah Penelitian Tindakan Sekolah (PTS). PTS adalah penelitian yang dilaksanakan oleh seorang Kepala Sekolah dalam rangka Pengembangan Keprofesian Berkelanjutan (PKB). Waitlem dan Risman (2017) menjelaskan bahwa PTS adalah sebuah penelitian yang dilakukan oleh Kepala Sekolah dan Pengawas Sekolah untuk meningkatkan kinerja sistem pendidikan dan mengembangkan manajemen sekolah supaya produktif, efektif, dan efisien.

Arikunto (2010) menjelaskan proses penelitian dilaksanakan dalam dua siklus, setiap siklusnya terdiri dari empat tahap yaitu: (1) perencanaan, (2) pelaksanaan, (3) pengamatan, (4) refleksi.

Subjek penelitian adalah guru SMP Negeri 5 Kecamatan Harau, baik yang sudah berstatus pegawai negeri sipil ataupun pegawai honorer yang berjumlah 8 orang. Peneliatian ini dilaksanakan di SMPN 5 Kecamatan Harau. SMPN 5 Kecamatan Harau yang terletak di daerah pedesaan. Lokasinya terletak di daerah perbukitan kira-kira $18 \mathrm{~km}$ dari ibu kota Kabupaten Lima Puluh Kota. Sekolah ini awal berdiri adalah sebagai sekolah Satu Atap yang satu lokasi dengan SDN 02 Harau.

Penelitian ini dilaksanakan selama 4 bulan. Penelitian dimulai pada bulan September 2019 dan berakhir tanggal 23 Desember 2019.

Penelitian ini dilaksanakan dalam 2 siklus. Setiap siklus terdapat 4 fase, perencanaan, pelaksanaan, pengamatan, dan evalusi.

\section{Siklus I}

1. Perencanaan

Pada tahap perencanaan ini peneliti menentukan langkah-langkah sebagai berikut : 1) Menentukan dan menetapkan guru sebagai subyek penelitian 2) Mempersiapkan instrumen telaah perangkat penilaian, 3) Meminta guru yang telah terpilih untuk menyerahkan perangkat penilaian mereka untuk dijadikan nilai pra siklus penelitian Tindakan sekolah, dan 4) Menentukan jadwal pelaksanaan penelitian.

2. Pelaksanaan Tindakan

Pada pertemuan 1, peneliti mengumpulkan para guru untuk memperoleh pelatihan berupa in haouse training (IHT) tentang bagaiman Menyusun perangkat penilaian dengan benar. Pada pertemuan ke dua, peneliti meminta guru untuk menyususn kisi-kisi ulangan harian dan pada pertemuan ke tiga, peneliti meminta guru menyususn soal pilihan ganda berdasarkan kisi-kisi yang telah dirancang pada pertemuan sebelumnya.

3. Pengamatan Peneliti mengamati Kisi-kisi dan soal pilihan ganda yang telah dirancang guru.

4. Refleksi

Setelah data siklus 1 diperoleh, maka dilakukan penilaian dan analisis hasil pengamatan. 


\section{Siklus 2}

1. Perencanaan tindakan

Pada tahap ini, peneliti merencanakan tindakan yang akan dilaksanakan dan menyusun jadwal pelaksanaan tindakan dengan guru yang diteliti. Peneliti mendata dan mencatat temuan-temuan pada siklus I untuk dibahas pada saat pelaksanaan Tindakan. Pada pelaksanaan Tindakan siklus II, peneliti akan focus pada permasalahan yang belum tuntas dicapai guru pada siklus I.

2. Pelaksanaan Tindakan

Pelaksananaan Tindakan pada siklus II ini sama dengan Tindakan yang dilakukan pada siklus I. Pada pertemuan 1, peneliti mengumpulkan para guru untuk memperoleh tentang perangkat penilaian yang telah disusun guru pada siklus I. Peneliti menyampaikan keunggulan-keunggulan yang telah dicapai guru dan kelemahan-kelemahan tentang menyusun perangkat penilaian dengan benar. Pada pertemuan ke dua, peneliti meminta guru Kembali untuk menyususn kisi-kisi ulangan harian 2 dan pada pertemuan ke tiga, peneliti meminta guru menyususn soal pilihan ganda yang digunakan untuk ulangan harian 2 berdasarkan kisi-kisi yang telah dirancang pada pertemuan sebelumnya.

3. Pengamatan

Peneliti menganalisis RPP berdasarkan instrumen penilaian RPP.

4. Refleksi

Peneliti dan guru sama melakukan perenungan tentang capaian yang diperoleh selama pelaksanaan In House Training. Berdasarkan hasil yang diperoleh peneliti memutuskan apakah penelituian dilanjutkan ke siklus III atau berhenti pada siklus II. Penghentian Tindakan berdasarkan kepuasan dan kriteria keberhasilan yang telah ditetapkan sebelumnya.

Data dikumpulkan melalui studi dokumen. Dimana peneliti menganalisis dokumen perangkat penilaian yang dirancang guru. Instrumen yang digunakan adalah lembar observasi penilaian hasil pembelajaran siswa dan analisis butir soal kualitatif bentuk tes pilihan ganda.

Data dianalisis secara deskriptif dimana peneliti mengolah data berdasarkan temuan pada lembar observasi dalam hal ini format analisis butir soal pilihan ganda dengan menggunakan persentase. Disini peneliti mengelompokkan kompetensi guru berdasarkan empat kategori, yaitu perolehan nilai anatara $90 \leq$ $\mathrm{A} \leq 100$ adalah Amat Baik (AB), $75 \leq \mathrm{B}<90$ adalah Baik (B), $60 \leq \mathrm{C}<74$ adalah Cukup (C), dan <60 adalah Kurang (K). Skor maksimum adalah 90 dan minimum adalah 30 .

Tindakan dalam penelitian ini dianggap berhasil apabila guru mampu menyusun perangkat penilaian dengan mencapai nilai minimal Baik untuk semua indikator pada kisi-kisi dan butir soal.

\section{HASIL PENELITIAN DAN PEMBAHASAN}

Pada tahap perencanaan menetapkan guru sebagai subyek penelitian. Peneliti juga mempersiapkan instrumen telaah perangkat penilaian. Meminta guru yang telah terpilih untuk menyerahkan perangkat penilaian mereka untuk dianalisis. Hasil analisis dijadikan acuan untuk penelitian Tindakan sekolah. Terakhir, peneliti Menentukan jadwal pelaksanaan penelitian. 
Pada pertemuan pertama, peneliti mengumpulkan guru dalam satu ruangan. Peneliti memberikan pelatihan tentang perangkat penilaian hasil belajar siswa. Peneliti menjelaskan diantaranya Langkah-langkah pengembangan soal. Kemuadian dilanjutkan dengan penjelasan tentang kisi-kisi soal yang baik. Selanjutnya, peneliti juga menjelaskan tentang spesifikasi butir soal. Spesifikasi butir soal adalah bagaimana guru membagi butir soal sesuai dengan alokasi waktu dan materi penting yang diajarkan. Prinsip penulisan soal (Valid, reliabel, Fair, transparan dan autentik) juga dijelaskan. Kriteria penulisan soal adalah Urgensi, Kontinuitas, Relevansi, dan Keterpakaian. Kaidah penulisan soal juga dijabarkan pada pelatihan ini.

Pelatihan In House Training (IHT) dilaksanakan pada hari Rabu tanggal 8 Agustus 2019. Pelatihan dilaksanakan pada sore hari sehabis guru mengajar. Sehingga pelaksanaan penelitian tidak mengganggu kegiatan wajib guru yaitu mengajar. Ada 8 orang guru yang mengikuti pelatihan (IHT) tentang perancangan perangkat penilaian hasil belajar siswa.

Pada pertemuan kedua, peneliti meminta guru merancang kisi-kisi soal untuk ulangan harian 1. Kegiatan dilaksanakan pada hari Selasa tanggal 14 Agustus 2019. Pada kesempatan ini peneliti membimbing guru selama pelatihan. Guru merancang kisi-kisi soal berdasarkan format yang telah diberikan pada pertemuan sebelumnya.

Pertemuan 3 dilaksanakan pada hari Selasa tanggal 21 Agustus 2019. Guru bekerja membuat soal ulangan harian berdasarkan kisi-kisi yang telah dirancang pada peretmuan 2. Selama guru bekerja, peneliti mengawasi dan membimbing guru yang belum paham tentang bagaimana merancang soal pilihan ganda dengan baik.

Dari hasil kerja guru pada pertemuan 1 dan 2 maka dapat diuraikan perolehan kompetensi guru dalam merancang perangkat penilaian sebagai berikut: Berdasarkan hasil temuan penelitian pada tabel di atas dapat dijelaskan bahwa pada siklus I guru sudah membuat kisi-kisi soal dengan baik. Diperoleh rata-rata nilai guru dalam membuat kisi-kisi soal 86,25 dengan peringkat Baik (B). Namun masih ada dua indikator yang perlu perhatian untuk ditingkatkan yaitu "Indikator soal merupakan hasil pengembangan dari IPK" dengan rata-rata perolehan 37,5 dan "Indikator Soal sudah memenuhi kriteria ABCD (Audience, Behaviour, Conditional, Degree)" dengan nilai 25. Kedua indikator ini termasuk pada predikat K (Kurang).

Dari temuan Siklus I diperoleh bahwa masih ada lima indikator yang diperoleh guru dalam peringkat Cukup. Indikator "Soal sesuai dengan indikator" diperoleh rata-rata nilai sebesar 67,71. "Pokok soal dirumuskan dengan singkat, jelas, dan tegas." diperoleh data 75,83. "Rumusan pokok soal dan pilihan jawaban merupakan pernyataan yang diperlukan saja" diperoleh nilai 79,79. Indikator "Panjang pilihan jawaban relatif sama" diperoleh nilai 75,63, dan indikator "Menggunakan bahasa yang sesuai dengan kaidah bahasa Indonesia, untuk bahasa daerah dan bahasa asing sesuai kaidahnya" diperoleh nilai 79,38.

Berdasarkan hasil temuan pada siklus I, peneliti merefleksikan bahwa masih ada beberapa indikator yang perlu ditingkatkan guru. Pada pembuatan kisi-kisi soal perlu perhatian khusus pada indikator "Indikator soal merupakan hasil pengembangan dari IPK" dengan rata-rata perolehan 37,5 dan "Indikator Soal sudah memenuhi kriteria ABCD (Audience, Behaviour, Conditional, Degree)" 
dengan nilai 25. maka pada siklus II, peneliti menitik beratkan pelatihan (IHT) pada kedua indikator tersebut.

Pada kompetensi perakitan butir soal berdasarkan kisi-kisi masih ada 5 dari 15 indikator yang diperoleh guru dengan predikat Cukup. Maka pelatihan pada siklus II lebih memperhatikan indikator yang masih pada kondisi lemah yang dicapai guru. Dengan demikian diharapkan pada siklus II dapat membantu guru dalam meningkatkan kompetensi mereka dalam merancang perangkat penilaian hasil belajar siswa dengan baik.

Pada tahap perencanaan di Siklus II, peneliti dan guru sebagai subyek penelitian menentukan jadwal peretemuan pada siklus II ini. Kemudian, peneliti mempersiapkan instrumen telaah kisi-kisi dan telaah butir soal. Disamping itu, peneliti membuat rekap kelemahan kompetensi yang akan ditingkatkan pada siklus II tersebut.

Pertemuan 1 dilaksanakan pada Selasa tanggal 3 September 2019. Kegiatan In House Training (IHT) dihadiri oleh delapan orang guru. Pada kesempatan ini, peneliti memaparkan kompetensi yang telah diperoleh guru baik yang telah memperoleh predikat Baik maupun yang masih Cukup. Untuk kompetensi yang masih cukup, peneliti memberikan penjelasan dan arahan tentang bagaimana merancang kisi-kisi yang baik dan benar, begitu juga dengan perakitan butir soal berdasarkan kisi-kisi yang telah dirancang.

Pertemuan 2 dilaksanakan pada hari Selasa tanggal 10 September 2019. Pada kesempatan ini, peneliti meminta guru merancang kisi-kisi soal ulangan harian 2. Peneliti membimbing langsung para peserta dalam merancang kisi-kisi. Pada kesempatan ini peneliti fokus memperhatikan pada indikator yang diperoleh Cukup pada siklus I.

Selasa tanggal 17 September 2019 adalah pelaksanaan pertemuan ke 3 siklus II. Semua peserta sangat serius dalam perakitan soal berdasarkan kisi-kisi yang telah mereka rancang pada pertemuan 2 minggu lalu. Pada akhir pertemuan, peneliti mengumpulkan baik kisi-kisi maupun soal yang telah dirancang guru untuk dilakukan penilaian.

Siklus II telah selesai dilaksanakan. Dari sepuluh indikaor pada instrumen penilaian kisi-kisi soal dapat dikerjakan guru dengan sangat baik. Hanya satu indikator saja yang berprediket Baik. Dengan demikian dapat disimpulkan bahwa kompetensi guru merancang kisi-kisi soal sudah Sangat baik.

Dari temuan penelitian bahwa kompetensi guru dalam merancang butir soal pilihan ganda adalah sudah Amat Baik. Hal ini terbukti perolehan nilai guru adalah antara 88,96 sampai 100. ini terbukti kompetensi guru dalam merancang soal sudah sangat baik.

Berdasarkan temuan pada siklus II bahwa semua indikator pembuatan kisi-kisi soal dan hasil analisis butir soal telah mencapai nilai minimal Baik, maka peneliti menghentikan penelitian tindakan sekolah ini hanya sampai siklus II saja.

Setelah dilaksanakan penelitian dengan menerapkan In House Training dalam dua siklus, maka diperoleh hasil tentang kompetensi guru dalam merancang perangkat penilaian Ulangan Harian di UPTD SMPN 5 Kecamatan Harau dari siklus I ke Siklus II. Rata-rata peningkatan adalah 9,90. Pada siklus I diperoleh rata-rata kompetensi guru sebesar 87,14\% dan pada siklus II diperoleh sebesar 97,04\%. Temuan penelitian menunjukkan terjadi peningkatan yang nyata terhadap kompetensi guru dalam merancang perangkat penilaian melalui In House Training 
(IHT). pelatihan yang dilaksanakan oleh kepala sekolah dalam rangka Pengembangan Keprofesian Berkelanjutan (PKB). Tujuan pelaksanaan penelitian tindakan sekolah ini adalah untuk meningkatkan kompetensi guru dalam merancang perangkat penilaian di UPTD SMPN 5 Kecamatan Harau. Latarbelakang masalah penelitian ini adalah bahwa guru belum mempersiapkan perangkat penilaian dengan maksimal.

Hasil temuan penelitian ini dapat pula disajikan seperti pada garfik di bawah ini:

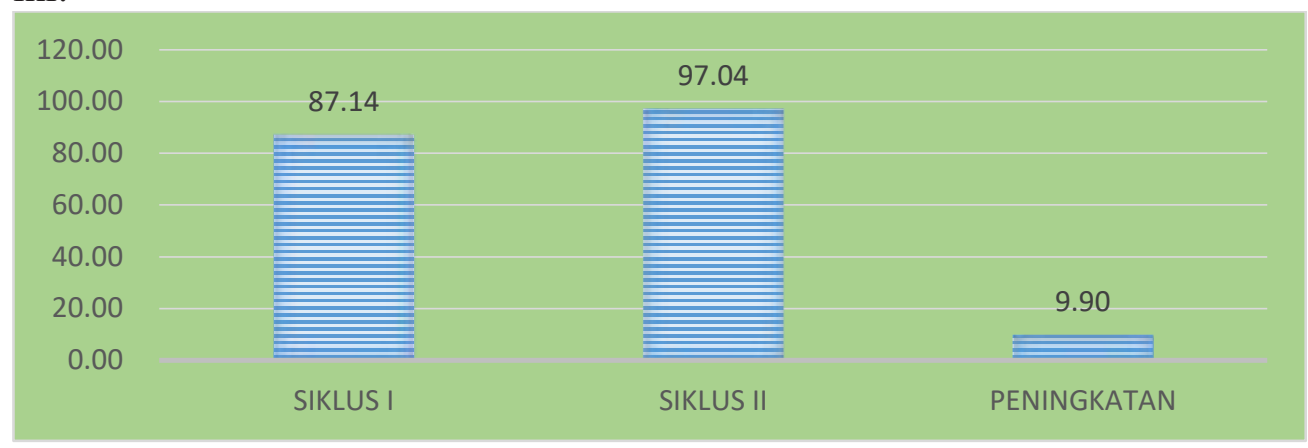

Grafik 1 : hasil temuan penelitian

Untuk lebih rinci temuan penelitian ini dapat dilihat pada grafik di bawah ini:

1. Materi Soal

Ada tiga indikator pada bagian Materi ini, yaitu Soal sesuai indikator, Pilihan Jawaban homogen dan logis, dan Setiap soal hanya ada satu jawaban yang benar. Pada indikator pertama terjadi peningkatan sebesar 21,25\%. Dari temuan penelitian, guru masih bermasalah dengan indikator tersebut pada siklus I, namun pada siklus II peneliti lebih memperhatikan guru dalam pembuatan kisi-kisi dan soal terutama pada indikator yang bermasalah. Maka terjadilah peningkatan pada siklus II. Indikator ke dua terjadi peningkatan sebesar 9,79\% dan indikator ke tiga terjadi peningkatan sebesar 10,21\%. Dari grafik tersebut dapat diambil kesimpulan bahwa terjadi peningkatan kompetensi guru dalam merancang perangkat penilaian ditinjau dari Materi soal.

2. Konstruksi Soal

Berdasarkan grafik di atas dapat dijelaskan bahwa secara umum temuan penelitian menggambarkan peningkatan kompetensi guru dari siklus I ke siklus II dalam merancang perenagkat penilaian di UPTD SMPN 5 Kecamatan Harau. Ada sembilan indikator pada bagian konstruksi soal dalam hal ini soal pilihan ganda. Tujuh dari sembilan indikator mengalami peningkatan dari siklus I ke siklus II. Peningkatan terjadi antara 4-23\%. Namun ada dua indikator dimana guru telah memiliki kompetensi yang amat baik dari siklus I yaitu 100\%. Jadi tidak terjadi peningkatan pada siklus II pada indikator "Pilihan jawaban tidak menggunakan pernyataan "Semua jawaban di atas salah" atau "Semua jawaban di atas benar" dan sejenisnya" dan "Butir soal tidak bergantung pada jawaban soal sebelumnya".

3. Bahasa Soal

Bagian ke tiga adalah Bahasa. Ada tiga indikator yang harus diperhitungkan dalam membuat soal ulangan ditinjau dari unsur bahasa yaitu "Menggunakan bahasa yang sesuai dengan kaidah bahasa Indonesia, untuk bahasa daerah dan 
bahasa asing sesuai kaidahnya, Tidak menggunakan bahasa yang berlaku setempat/tabu, dan Pilihan jawaban tidak mengulang kata/kelompok kata yang sama, kecuali merupakan satu kesatuan pengertian". Dari grafik terlihat bahwa guru sudah mampu menggunakan bahasa yang baik dan benar dalam membuat soal. Dari temuan terlihat bahwa pada siklus I guru sudah memiliki nilai yang baik. Pada indikator "Menggunakan bahasa yang sesuai dengan kaidah bahasa Indonesia, untuk bahasa daerah dan bahasa asing sesuai kaidahnya" terjadi peningkatan sebesar $20 \%$ dimana perolehan nilai pada siklus I adalah 79,38 dan pada siklus II diperoleh nilai sebesar 99,38. "Tidak menggunakan bahasa yang berlaku setempat/tabu" sudah diperoleh nilai maksimal pada siklus I yaitu 100, maka pada siklus II tetap nilai 100. Terakhir indikator "Pilihan jawaban tidak mengulang kata/kelompok kata yang sama, kecuali merupakan satu kesatuan pengertian" terjadi peningkatan sebesar $4,58 \%$.

Berdasarkan temuan dari penelitian tindakan sekolah yang berjudul "Peningkatan Kompetensi Guru Dalam Merancang Perangkat Penilaian Hasil Belajar Melalui In House Training (IHT) Di UPTD SMPN 5 Kecamatan Harau Tahun Pelajaran 2019/2020 terjadi peningkatan kompensi guru dengan baik. Oleh sebab itu dapat disimpulkan bahwa In House Training (IHT) dapat meningkatkan kompetensi guru dalam merancang perangkat penilaian hasil belajar.

\section{KESIMPULAN DAN SARAN}

Dari temuan penelitian dapat dapat disimpulkan bahwa melalui In House Training (IHT) dapat meningkatkan kompetensi guru dalam merancang perangkat penilaian hasil belajar siswa. Perolehan data peningkatan adalah sebesar 9,90\% pada kompetensi merakit soal dan $12,5 \%$ pada kompetensi guru merancang kisi-kisi soal.

Berdasarkan hasil yang diperoleh, peneliti menyarankan sebagai berikut:

1. Guru agar selalu meningkatkan kompetensi terutama pada kompetensi merancang perangkat penilaian hasil belajar dengan demikian mutu pembelajaran juga meningkat.

2. Kepala sekolah sebagai manajer, supervisor, dan kewirausahaan harus selalu berusaha meningkatkan kompetensi diri dan guru agar tercapai tujuan pendidkan dengan baik.

3. Peneliti selanjutnya perlu melaksanakan penelitian tentang permasalahan lain di sekolah.

\section{DAFTAR PUSTAKA}

Arikunto, S. (2006). Prosedur Penelitian Suatu Pendekatan Praktik. Jakarta: Rineka Cipta.

Danim, Sudarwan. 2012. Motivasi Kepemimpinan dan Efektivitas Kelompok. Jakarta : Rineka Cipta.

Depdiknas, 2007, Panduan Penulisan Soal Pilihan Ganda, Jakarta: Pusat Penilaian Pendidikan Balitbang. 
Kemdikbud. 2017. Panduan Penilaian oleh Pendidik dan Satuan Pendidikan untuk Sekolah Menengah Pertama. Jakarta: Direktorat Pembinaan Sekolah Menengah Pertama

Rusman. 2012. Belajar dan Pembelajaran Berbasis Komputer Mengembangkan Profesionalisme Guru Abad 21. Bandung: Alfabeta

Sujoko, Alfaris. 2012. Peningkatan Kemampuan Guru Mata Pelajaran Melalui In House Training. Jurnal Pendidikan Penabur-No.18 tahun ke-11/Juni

Waitlem dan Risman. 2017. Praktik Praktis Penulisan Karya Tulis Ilmiah untuk Guru. Padang. CV, Visigraf 